\title{
Recognizing the Islamic Banking Consumer Behaviour from the Perspective of Product Knowledge, Brand Awareness and Attitude
}

\author{
Dudi Permana \\ Universitas Mercu Buana
}

\begin{abstract}
This paper aims to identify the intention behavior of consumer in Indonesian Islamic banking, from the perspective of product knowledge, brand awareness and attitude. Data collected were then analyzed using structural equation modeling via Smart PLS.Research have found that product knowledge and brand awareness have positive significant impact on attitude, and attitude have positive significant impact on intention toward being the customer of Indonesian Islamic banking
\end{abstract}

Keywords: Product Knowledge, Brand Awareness, Attitude, Intention and Islamic Banking

DOI: $10.7176 / \mathrm{JMCR} / 61-03$

Publication date:October $31^{\text {st }} 2019$

\section{Introduction}

Modern Islamic economics on the international stage began in the 1970s characterized by contemporary economic experts such as Kursyid Ahmad, An-Naqvi, M.Umer Chapra, and others. In line with that later formed the Islamic Development Bank in 1974. Islamic Development Bank (1974) which is established by countries that are members of the Islamic Conference. IDB itself provides fee-based and profit sharing services and declares itself based on Islamic Syariah.

The establishment of Islamic Development Bank has become an inspiration and motivation for Muslim countries to establish Islamic financial institutions. IDB received many requests for assistance to establish these institutions. Then in the 1970s the establishment of Islamic Banks was conducted in various countries such as: Nasir Social Bank (1971), Dubai Islamic Bank (1975), Kuwait Finance House (1977), Bahrain Islamic Bank (1979), Even in Europe there are banks established in 1983 namely The Islamic Bank International of Denmark. In terms of infrastructures, institutions that are expected to become accelerators of the global Islamic financial system have also been established, such as the Accounting and Auditing Organization for Islamic Institutions (AAOIFI) and the International Financial Service Board (IFSB). (www.kompasiana.com)

Indonesia has the advantage of the structure of syariah financial development is the regulation where the authority issued Islamic financial fatwa centered on an independent institution namely the National Syariah Council of Majelis Ulama Indonesia (MUI) different from in other countries fatwas can be issued by individual scholars so that the possibility of difference of regulation each other. The National Syariah Council-Majelis Ulama Indonesia (DSN-MUI) was formed in order to realize the aspirations of Muslims regarding economic issues and encourage the application of Islamic teachings in the field of economy implemented in accordance with the guidance of Islamic law.

Bank Indonesia as the regulator of banking in Indonesia is very supportive of the development of Syariah banking, because the macro development of Islamic banks can give the support of the stability of the financial system and the national economy. Here the role of all instruments in the operation of a banking, especially the regulator, namely Bank Indonesia (BI), controller (Syariah Advisor) in the National Syariah Board (DSN) and Syariah Supervisory Board (DPS) Majelis Ulama Indonesia and management of banking operations become important to improve the development and performance of Syariah banking in Indonesia.

In this respect, Bodibe, et al (2016) propose that five dimensions of awareness, product knowledge, community, social norms and religion. Consistent with the above explanation, this study aims to establish whether there are the relationships between brand awareness and product knowledge on attitudes, and whether attitudes influence the intention to save at Islamic banks.

\section{Literature Review}

\subsection{Behavioral Intention}

Behavioral intentions according to Mowen (2012) are defined as consumers' desire to behave in a certain way in order to own, discard and use products or services. So consumers can form the desire to seek information, tell others about their experience with a product, buy a particular product or service, discards certain products. According to Schiffman and Kanuk (2010), intention to behave is the frequency of purchase or the proportion of total purchases from buyers who are loyal to a particular brand. According to Peter and Olson (2013) the intention to behave (behavioral intention) is a proportion that connects itself to the actions that will come. 


\subsection{Brand Awareness}

Brand awareness means the ability of consumers to recognize and remember brands in different situations. Brand awareness consists of brand recall and brand recognition. Brand recall means when consumers look at product categories, they can remember the exact brand name, and brand recognition means the consumer has the ability to identify the brand when there is a brand cue (Aaker 2009).

Kotler \& Keller (2012) show that brand awareness can be distinguished from depth and breadth. Depth means how to make consumers to remember or identify brands easily, and the express breadth concludes when consumers buy a product, the brand name will come to their minds at once. From the definition can be concluded that brand awareness is a person's ability to remember or recognize a particular brand of a product.

\subsection{Product Knowledge}

According to Sumarwan (2011) product knowledge is a combination of several kinds of information about the product. According Nitisusastro (2012) consumers need to know about the characteristics of a product, if consumers are less aware of information about the characteristics of a product can be wrong to make a buying decision.

\subsection{Attitude}

According to Engel in Sangadji and Sopiah (2013) Attitude is a mental and nerve associated with readiness to respond, organized through experience, and has a directional or dynamic influence on behavior. Attitudes are also called the most specific and indispensable concepts in contemporary social psychology. Attitude is also one of the most important concepts that marketers use to understand consumers.

Meanwhile, according to Lapierre in Azwar (2013) defines "attitude as a pattern of behavior, tendency, or anticipatory readiness, predisposition to adapt in social situations, or simply, attitude is a response to conditioned social stimuli.

\subsection{Theoretical Perspective and Hypothesis Development}

The American Marketing Association in Kotler and Keller (2012) brand is a name, sign, term, symbol, design, or a combination of all that is intended to identify an item or service from a seller or group of sellers and to distinguish it from competitors. Brand awareness becomes one of the factors that influence consumer attitude (attitude), this is in line with the results of research Bodibe et al (2016) which reveals that brand awareness has a positive relationship to attitude. Jaffar's research results (2013) say that brand awareness has a positive relationship to attitudes, while the study of Sharaai (2015) shows that brand awareness has a significant and positive relationship to attitudes. Based on the argument, it proposed that :

hypothesis 1.1 : Brand awareness has a positive and significant influence on attitudes.

In previous research conducted by Rohmatun and Dewi (2017) mentioned that the knowledge of the products have a significant effect on attitude. Jaffar's research (2013) states that knowledge has a positive relationship to attitudes. The results of Kusuma and Untarini (2016) showed that product knowledge has a positive relationship and significant influence on attitude. Based on the above explanation, it is proposed :

hypothesis 1.2 : Product knowledge has a positive and significant influence on attitudes.

Attitude is one of the stages in the evaluation of alternatives that can later form the intention to buy. Mirawati's research, et al (2016) revealed that entrepreneurial attitudes have a positive and significant effect on the intention to become entrepreneurs. Based on Saptari and Sudiarti's (2013) research, there is a significant relationship between attitude and intention. but the results of Kusuma and Untarini's research (2016) showed that attitudes have a positive relationship and a significant influence on buying intention, but the influence of attitudes on buying intention is quite small. Therefore, it is proposed that:

hypothesis 1.3 : Attitude has a positive and significant influence on intention. 
Figure 1. Research Framework

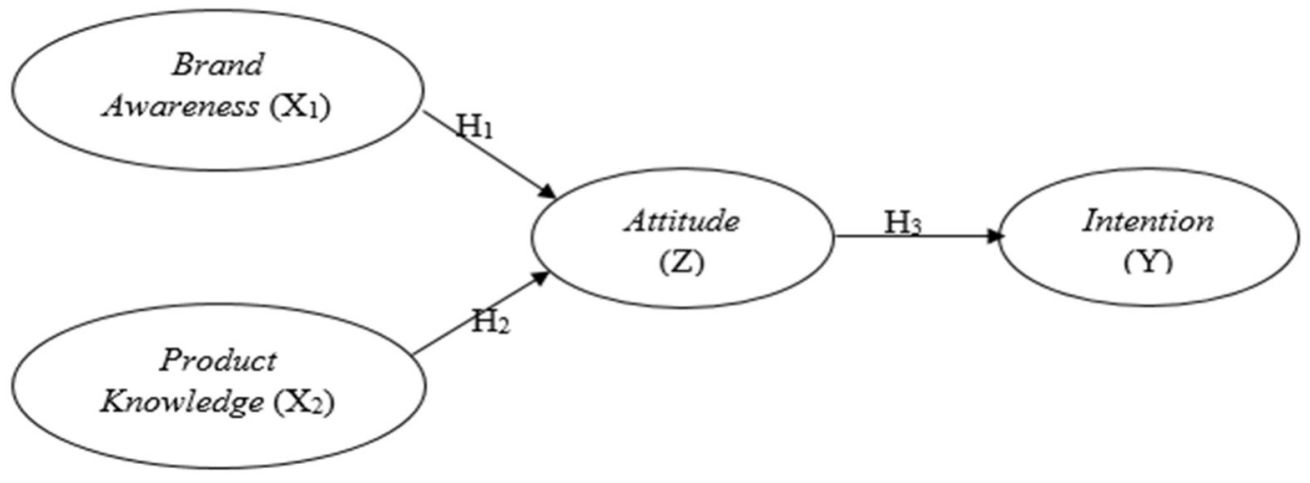

\section{Methodology}

\subsection{Population and Sample}

According Bougie et al (2010) population is a generalization region consist of objects and subjects that have certain qualities and characteristics set by researchers to be studied and drawn the conclusions. Population can facilitate researchers in his research. In this study population is West Jakarta people who have never used Islamic bank. Due to the large population and researchers it is impossible to study everything in the population. So, it carried out the sampling of the population under study with Non Probability Sampling technique used is Purposive sampling technique. According to Hair (2012), it states that the appropriate sample size in the SEM equation method is 100-200 samples, and depending on the number of parameters estimated, ie the number of samples 510 multiplied by the number of indicators. Based on the number of indicators $(5 \times 17=85)$ and $(10 \times 17=170)$. In this study researchers took 85 samples.

\subsection{Measurement instrument}

The questionnaire was divided into four sections with each section separated by a specific heading. Instructions were clearly and precisely stated after each heading for ease of the respondents. The background of the respondent was presented in the final section of the questionnaire. This procedure was adopted following suggestions that sensitive questions were best set towards the end of the questionnaire.

3.2.1 Brand Awareness

Aaker in Handayani et al (2010), defines brand awareness is the ability of potential consumers to recognize or remember that a brand belongs to a particular product category. this instrument consists of four items, about the extent to which the ability of consumers to recognize the brand and distinguish it with other brands. The respondents assessment of the effectiveness of brand awareness items were obtained on a 5-point Likert-type scale. 3.2.2 Product Knowledge

Product Knowledge, According to Sumarwan (2011) product knowledge is a collection of several kinds of information about the product. This instrument consists of six items, it is about the extent of consumer knowledge about a product before making a purchase decision. The respondents assessment of the effectiveness of product knowledge items were obtained on a 5-point Likert-type scale.

3.2.3 Attitude

Attitude, According to Ariani (2013) attitude is a form of reaction of one's feelings towards an object, whether feeling support or not supportive, impartial or impartial, likes or dislikes that cause a certain effect on one's behavior. This instrument consists of three items, related to what the consumer thinks before making a purchase of a product. The respondents assessment of the effectiveness of attitude items were obtained on a 5-point Likerttype scale.

\subsubsection{Intention}

According to Schiffman and Kanuk (2010), intention to behave is the frequency of purchase or the proportion of total purchases from buyers who are loyal to a particular brand. this instrument consists of four items, related to the buying interest of a consumer after knowing all the information about the product. The respondents assessment of the effectiveness of attitude items were obtained on a 5-point Likert-type scale.

\section{Analysis}

A total of 85 responses were received at the end of the data collection process. profile of respondents can be analyzed in accordance with five aspects, namely gender, age, education level, occupation and amount of income. of 85 respondents, $51.8 \%$ of respondents were female and $48.2 \%$ male. the majority of respondents, 60 people aged between 21-25 years, as many as 16 respondents aged between $26-30$ years, then the age range 31-35 years 
there are 6 respondents, and only 3 respondents are aged $>35$ years. almost the majority of respondents have last junior high school education as many as 58 people, while there are 2 respondents who did not finish junior high school. as many as 48 respondents are employees, the rest are followed by various other types of work. income of 49 respondents mostly ranges from Rp.3.500.000 - Rp.5.000.000.

\section{Results}

PLS (Partial Least Square) is a component analysis method or variance Based Structural Equation Modeling where in data processing is a program of Partail Least Square (Smart-PLS) version 3.0. PLS (Partial Least Square) is an alternative model of convarience based SEM. PLS is intended for causal-predictive analysis in situations of high complexity and low theory support. (Ghozali, 2014).

\subsection{Measurement model}

\subsubsection{Convergent validity}

Test the convergen validity of each construct indicator. According to Chin in Ghozali (2014), an indicator is said to be a good valid if the value is greater than 0.70 while the loading factor of 0.50 to 0.60 can be considered sufficient. Based on these criteria, then when the loading factor is below 0.50 then the indicator must be removed from the model.

\section{Evaluation Measurement Model (Designing Outer Model)}

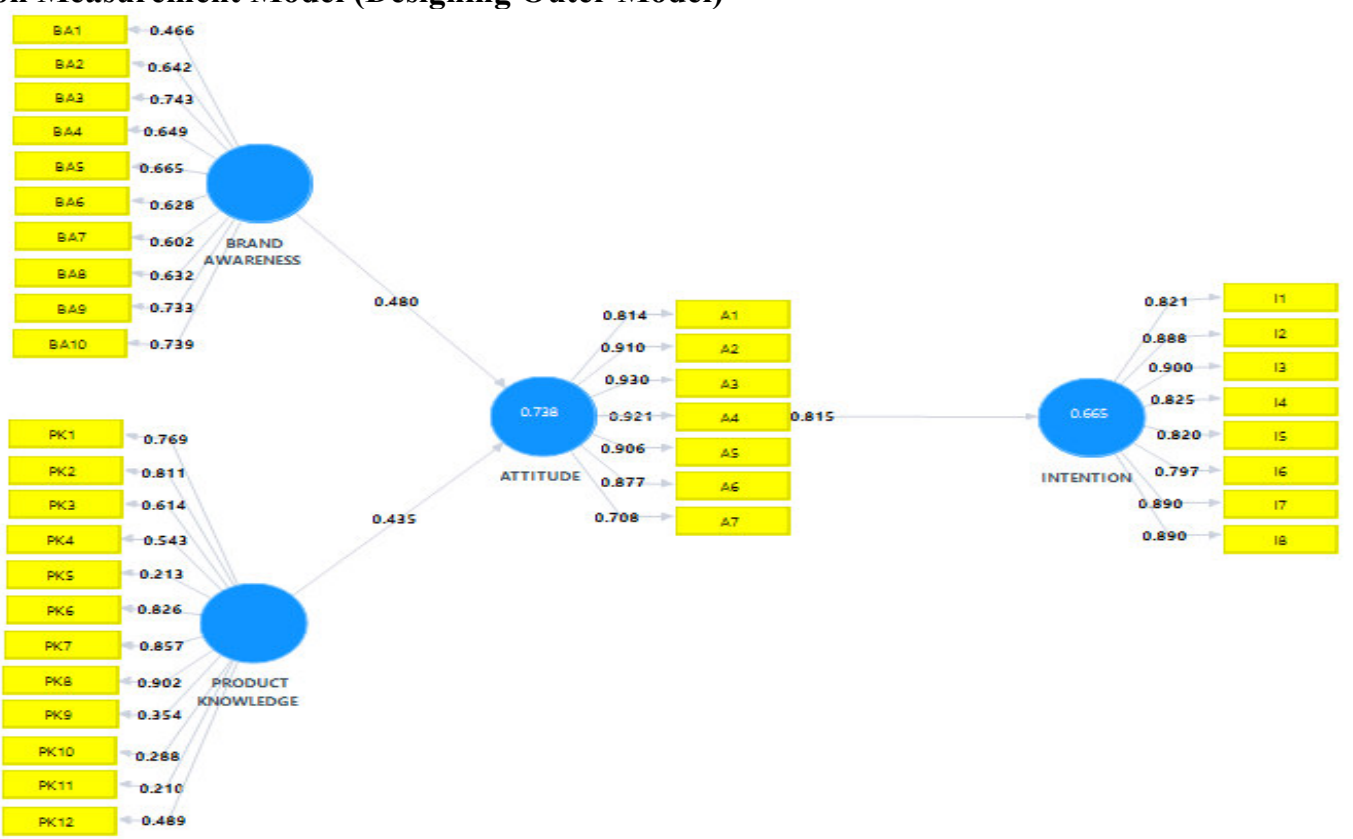

In convergent validity testing individual reflexive measure is said to be high if it correlates more than 0.70 with the construct that you want to measure. However, for the initial research phase, the development of measurement values of loading values 0.50 to 0.60 is considered sufficient (Chin, 1998 in Ghozali, 2014).

Loading factor below 0.7 should be deleted, then re-estimate. the amount of loading factor re-estimation results indicate that all indicators have good validity because it has a loading factor of more than 0.7. The AVE value indicates that all constructs have a potential reliability of greater than 0.5 . the next examination of convergent validity is reliability. the recommended AVE value should be greater than 0.5 (Ghozali, 2014).

5.1.2 Discriminant Validity

Discriminant validity can be done by cross loading examination that is if the construct correlation with the measurement item is greater than the size of the other construct.

Table 1. Factor loadings and reliability

\begin{tabular}{llll}
\hline Items & Composite R & AVE & Cronbach Alpha \\
\hline Attitude & 0.956 & 0.756 & 0.945 \\
Brand Awareness & 0.920 & 0.852 & 0.826 \\
Intention & 0.956 & 0.731 & 0.947 \\
Product Knowledge & 0.932 & 0.734 & 0.909 \\
\hline
\end{tabular}


Table 2. Discriminant Validity Test ( Fornell-Larcker )

\begin{tabular}{|l|r|r|r|r|}
\hline Indikator & \multicolumn{1}{|c|}{ Attitude } & \multicolumn{1}{c|}{$\begin{array}{c}\text { Brand } \\
\text { Awareness }\end{array}$} & \multicolumn{1}{|c|}{$\begin{array}{c}\text { Prtention } \\
\text { Knowledge }\end{array}$} \\
\hline Attitude & 0.870 & & & \\
\hline Brand Awareness & 0.776 & 0.923 & & \\
\hline Intention & 0.817 & 0.745 & 0.855 & \\
\hline Product Knowledge & 0.790 & 0.751 & 0.675 & 0.857 \\
\hline
\end{tabular}

Sumber: SmartPLS 3.0

Discriminant validity can be examined by comparing the squared correlations between the constructs and the variance extracted for constructs (Fornell and Larcker). As show in table 2, the squared correlation for each constructs were less than the square root of the average variance extracted by the indicators measuring that constructs, indicating adequate discriminant validity. Thus the measurement model demonstrated adequate convergent and discriminant validity.

The Fornell Larcker Criterion above shows that the value of $\sqrt{ } \mathrm{AVE}$ attitude variable is 0.870 , while the highest correlation value of attitude variable with other variables is 0.776 . Thus $\sqrt{ }$ AVE attitude variable is greater than attitude correlation with other variables. Similarly, in other variables that show $\sqrt{ }$ AVE is greater than the correlation between variables, so the discriminant validity condition with $\sqrt{A V E}$ has been met.

\subsection{Structural model}

Structural Model or Hypothesis Test (Designing the inner model), namely the development of a model based on theoretical concepts in order to analyze the relationship between exogenous and endogenous variables that have been described in the conceptual framework. Estimated values for the relationship between pathways in the structural model must be significant. This significant value is obtained by a bootstrapping procedure. Looking at the significance of the hypothesis by looking at the parameter coefficients and the significant value of $t$ statistics on the bootstrapping report algorithm, the significant value of $t$ statistic must be $<1.96$.

Table 3. Summary of the structural model

\section{Original Sample (O) T Statistic information conclusion}

$\mathbf{B A} \rightarrow \mathbf{A} \quad 3,419 \quad 3,113 \quad$ Significant $\quad$ hypothesis accepted

$\mathbf{P K} \rightarrow \mathbf{A} \quad 0,475 \quad 3,069 \quad$ Significant hypothesis accepted
$\mathbf{A} \rightarrow \mathbf{I}$
0,817
16,329
Significant
hypothesis accepted 
Figure 3. The structural model

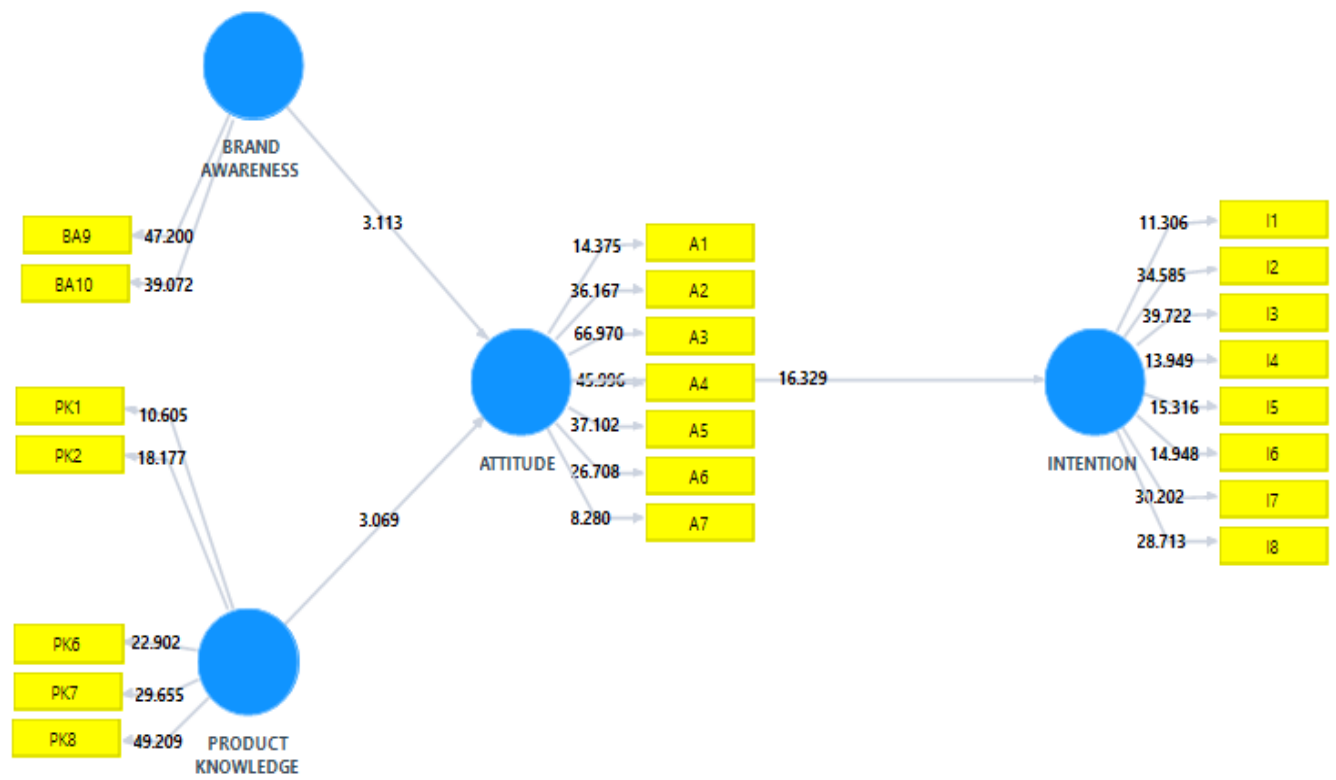

Based on table 3 above shows that brand awareness has a positive and significant effect on attitude, it can be seen from the t-count is 3.113 greater than $t$ - table of 1.96 with error rate of $0.05(5 \%)$. The value of original sample estimate is positive that is 0,419 indicating that relationship between brand awareness to attitude. While for the variable of product knowledge have positive and significant influence to attitude, it is indicated by t-count value is 3,069 bigger than t-table 1,96 with error rate $0,05(5 \%)$. The original sample estimate value is positive that is 0.475 indicating that the direction of relationship between product knowledge to attitude is posistif. Similarly, the attitude has a positive and significant impact on intention, this is indicated by a t-count value is 16.329 greater than $t$ - table 1.96 with a error rate of $0.05(5 \%)$. The original sample estimate value is positive that is 0.817 indicating that the direction of relationship between attitudes toward intention is positive. Thus it can be said that hypothesis $\mathrm{H} 1, \mathrm{H} 2$, and $\mathrm{H} 3$ in this research accepted.

\section{Discussion and implications}

This study confirms that brand awareness has a significant effect on Attitude. These results indicate that brand awareness has an important role in influencing attitude towards Islamic banks. The results of this hypothesis are consistent with the results of a study by Bodibe et al (2016) which revealed that brand awareness has a positive relationship to attitudes, and based on research Jaffar (2013) says that brand awareness has a positive relationship to attitudes, while Sharaai's (2015) that brand awareness has a significant and positive relationship to attitudes. This means that the greater a person's brand awareness of the Islamic bank brand, the greater the positive attitude of someone to the brand of Islamic banks. In other words, brand awareness is an important thing to note so that the attitude towards the brand of Islamic banks is more positive, because this is related to whether consumers are aware of the existence of the Islamic bank brand or not.

Product Knowledge has significant effect on Attitude. These results indicate that product knowledge has an important role in influencing a person's attitude towards Islamic banks. This means that if someone has knowledge of what products are in Islamic banks properly, the attitude of the person will be more positive and interested in using Islamic banks when they are going to save. The results of this hypothesis are in line with research conducted by Rohmatun and Dewi (2017), mention that knowledge has a significant effect on attitude.

Attitude has a significant effect on intention or intention to use bank syraiah. These results indicate that attitudes have an important role in influencing one's intentions to use or save in sharia banks. This means that the more positive attitude of a person to the Islamic bank it will increasingly affect his intention to save at sharia banks. These results are in line with research conducted by Kusuma and Untarini (2016) indicating that attitudes have a positive relationship and a significant influence on purchasing intentions, but the influence of attitudes on purchasing intentions is quite small. Attitude is one of the stages in the evaluation of alternatives that can build the intention to buy later. Research Mirawati, et al (2016) revealed that the attitude of entrepreneurship has a positive and significant impact on the intention to become an entrepreneur. Based on research Saptari and Sudiarti (2013) known there is a significant relationship between attitudes with intention. 


\section{Limitations and future research}

In designing this research, there are limits to the methodology for conducting effective research and focusing on the important elements of this study. This research is still not done without limitation, one of which is that this research focuses on Islamic banks in general and only depends on randomly distributed questionnaire data. Considering the extent of the area of Islamic banks in Indonesia. So it is not possible to research all existing Islamic banks.

For further researchers who want to do similar research, it is advisable to use other variables besides brand awareness, product knowledge and attitude that can affect the intention or intention to save on Islamic banks, because there are other factors that can explain the results in this study such as brand trust, marketing communication, reference groups, and religiosity.

\section{REFERENCE}

Aaker, D. (2009). Managing Brand Equity. New York: John Willey \& Sons, Inc.

Ariani, R. (2011). Hubungan Antara Iklan Rokok Dengan Sikap dan Perilaku Merokok Pada Remaja. Semarang: Universitas Diponegoro.

Azwar, S. (2013). Metode penelitian. Yogyakarta: Pustaka Pelajar.

Bodibe, S., Chiliya, N., \& Chikandiwa. 2016. The Factors Affecting Customers' Decision to Adopt Islaic Banking. Volume II. Issue 4.

Ghozali, I. (2014). Metode Alternatif Dengan Partial Least Square, Edisi 4. Semarang: Universitas Diponegoro.

Handayani, Desy, \& all. (2010). The Official MIM Academy Coursebook Brand Operation. Jakarta: Esensi Erlangga Group.

Jaffar, M. A., \& Musa, R. 2013. Determinants of Attitude towards Islamic Financing Among Halal-Certified Micro and SMEs : A Proposed Conceptual Framework. Vol.1 No 8.

Kotler, P., \& Keller, K. L. (2012). Marketing Management. Edisi 14. New Jersey: Prentice-Hall Published.

Kusuma, I. D., \& Untarini, N. 2014. Pengaruh Pengetahuan Produk Terhadap Niat Beli Dengan Sikap Sebagai Variabel Intervening. 2(4)

Nitisusastro, M. (2012). Perilaku Konsumen Dalam Perspektif Kewirausahaan. Bandung: Alfabeta.

Peter, J., \& Olson, J. (2013). Perilaku Konsumen dan Strategi Pemasaran. Jakarta: Salemba Empat.

Rohmatun, A. H., \& Dewi, C. K. 2017. Pengaruh Pengetahuan Dan Religiusitas Terhadap. Ecodemica Journal, 27-35.

Sangadji, E. M., \& Sopiah. 2013. Perilaku Konsumen: Pendekatan Praktis disertai Himpunan Jurnal Penelitian. Yogyakarta: Andi Off Set.

Saptari, A. F., \& Sudiarti, T. 2013. Hubungan Sikap dan Pengetahuan Dengan Niat Mendukung Praktik Pemberian ASI Eksklusif Pada Mahasiswa Magister Pria Universitas Indonesia.

Schiffman, L. G., \& Kanuk, L. L. (2010). Perilaku Konsumen. Jakarta: PT. INDEK.

Sharaai, E. A. (2015). Understanding The Effect Of Environmental Studies In Lifestyle By Analyzing The Awareness, Knowledge And Attitudes Of Faculty Of Environmental Studies' Students In UPM Regarding The Consumption Of Eco Label Products. Australian Journal of Basic and Applied Sciences, 106-109.

Sugiyono. 2013. Metode Penelitian Bisnis. CV. Alfabeta.

Suwarman, U. 2011. Perilaku Konsumen Teori dan Penerapannya Dalam Pemasaran. $2^{\text {nd }}$ Edition. Jakarta: PT. Ghalia Indonesia. 